\title{
The effect of teacher work motivation and the leadership of schools on teachers performance in elementary school
}

\author{
Ahmad Irhan ${ }^{1}$, Syarwani Ahmad ${ }^{2}$, Destiniar Destiniar ${ }^{2}$ \\ ${ }^{1}$ Sekolah Dasar Negeri Gugus 3 Lengkiti, Indonesia \\ ${ }^{2}$ Universitas PGRI Palembang, Indonesia
}

\begin{tabular}{l} 
Article Info \\
\hline Article history: \\
Received Jul $11^{\text {th }}, 2021$ \\
Revised Aug $19^{\text {th }}, 2021$ \\
Accepted Aug $30^{\mathrm{h}}, 2021$ \\
\hline
\end{tabular}

\section{Keyword:}

Teacher work motivation Principal leadership Teacher performance

\begin{abstract}
This is to determine the effect of work motivation and principal leadership together on the performance of teachers in SD Negeri Lengkiti District. In this study, quantitative research methods were used and the research design was in the form of an influence study, namely to determine the effect of the three variables, namely the independent or independent variable Teacher Motivation (X1), Principal Leadership (X2) and the dependent or dependent variable Teacher Performance $(\mathrm{Y})$. The results of the study can be concluded as follows: 1) The variable of work motivation of the SD Negeri Lengkiti District teachers is in the sufficient category, 2) The leadership variable of the principal of SD Negeri Lengkiti District is in the good category, 3) The work motivation of the teacher and the leadership of the principal is factors that can improve teacher performance.
\end{abstract}

C 2021 The Authors. Published by IICET.

This is an open access article under the CC BY-NC-SA license (https://creativecommons.org/licenses/by-nc-sa/4.0

\section{Corresponding Author:}

Irhan, A.,

Sekolah Dasar Negeri Gugus 3 Lengkiti, Indonesia

Email: ahmadirhan12@gmail.com

\section{Introduction}

In Indonesia, schools must sincerely carry out their duties and functions to achieve the national goals as stated in Law No. 20 of 2003 concerning the National Education System. Where National Education has a function in developing abilities and shaping the character and civilization of a nation with dignity in order to educate the nation's life, aims to develop the potential of students to become human beings who believe and have devotion to God Almighty, have noble character, are healthy, independent and become citizens A democratic and responsible country.

An educational institution can be said to be of high quality if there are professional educators who have a high sense of responsibility for their fields and have high moral and character values to be recognized as educators. For this reason, improving the quality of education is an absolute must, because then the quality of existing human resources will be affected.

School organizations are composed of various elements, both individuals and groups that work together to achieve educational goals. Without prejudice to other elements of the school organization, the principal and teacher are internal personalities who have an important role in determining the success of an educational process. 
The professional competence of teachers plays an important role in achieving optimal teaching goals. Given the important role of teachers, schools need to improve teacher professional competence so that the teaching objectives, vision and mission of the school can be achieved.

Teacher professional competence is part of the competencies that must be possessed by every teacher in the Law of the Republic of Indonesia Number 14 of 2005 concerning teachers and lecturers that teachers must have four competencies, namely pedagogic, personality, social, and professional obtained through professional education. This competency can also be seen in Permendiknas Number 16 of 2007.

[1] in an effort to provide quality formal education is closely related to carefulness and accuracy in identifying, formulating, packaging, and describing strategic policies and educational operational programs. Therefore, the management of educational activities in schools should also have good planning, effective and efficient organization of human resources, mobilizing teachers and school personnel according to their fields so that their performance increases, and carry out continuous control and supervision.

This means that the managerial abilities of school principals and professional service education personnel need to be developed and functioned optimally. Therefore, schools as the foremost work units that are directly related to real needs in the field of education, it is time to have work autonomy in carrying out management in their schools. Under the leadership of a professional school principal, teachers are expected to be able to present and develop themselves according to their potential which in turn can improve the quality of education in their institutions.

Thus, public trust in formal educational institutions is increasing. Furthermore, according to [2] the duties and responsibilities define the principal, namely managing the school, collecting, utilizing, and optimally mobilizing all the potential of the school to achieve goals. To carry out this task as well as possible, there are three main types of skills that must be possessed by the principal as an education leader, namely technical skills, communication skills (human relations skills), and conceptual skills (conceptual skills).

According to the assessment of some teachers who support the success of principal leadership is based on their ability to lead. The key to the smooth work of the principal lies in the stability, emotion, and selfconfidence which are the psychological foundations for treating staff fairly, exemplifying behavior, and behaving in carrying out tasks.

The principal functions as a communicator whose job is to act as an intermediary for passing instructions to teachers, channeling the aspirations of educational institutions to teachers, channeling the aspirations of school personnel to educational institutions, and channeling the aspirations of students, parents, and the community.

Likewise, teacher motivation is divided into two types, namely internal motivation and external motivation. Internal motivation or motivation that comes from within is related to the awareness of the teacher himself to be able to work better, among others: The desire of the teacher to educate students can encourage him to carry out learning tasks better. Such teachers have a tendency to be more creative and innovative in developing their abilities as educators. While external motivation or motivation that comes from outside includes compensation in the form of materials such as salaries, allowances, etc., as well as nonmaterial compensation such as career development, which has a significant driving force in efforts to improve teacher performance.

Performance is the result or overall success rate of a person during a certain period in carrying out a task compared to various possibilities, such as standard work results or targets or criteria that have been mutually agreed upon. [3] in their research, explained that teacher performance is still a problem that needs attention.One of the indicators is a lack of discipline and teacher mastery of subject matter and teaching methods are not optimal. Thus, the professional quality, quality and competence of teachers are still deemed not meeting standards. Teacher performance that is oriented towards mastering theory and rote memorization, causing students to not develop optimally and intact.

It is predicted that low teacher performance is due to a lot of it coming from within the individual teacher and from outside. In addition, the low teacher performance is influenced by, among others, competence, work discipline, job satisfaction in the organization where the teacher teaches, the leadership of the principal, as well as the existence of government policies on education. This is in line with [4] opinion, that performance is influenced by several factors including: work environment, organizational culture, leadership and work motivation, work discipline, salary, job satisfaction and other factors. Principal leadership has a significant impact. on teacher performance. 
The same thing was stated [5] which states that the leadership of the principal has an influence on teacher performance so that teacher performance cannot be separated from the influence of the principal's leadership. Because the better the leadership of the principal, the more it will improve the performance of teachers in carrying out their duties as educators. Thus the teacher will be more enthusiastic in fostering students both academically and non-academically. The teacher as an individual in the school organization is obliged to carry out all the duties and work assigned, to achieve all of this requires the ability and expertise of each teacher as well as strong motivation that spurs the morale of the teacher. In addition, [6] also suggests factors that can affect a person's performance, including training and work experience, education, personality attitudes, organizations, leaders, social conditions, individual needs, physical conditions of the workplace, abilities. , work motivation and so on.

Principal leadership and work motivation are some of the variables that also influence performance. To achieve the success of school principal leadership requires knowledge and ability to create a conducive working situation and climate, thereby generating motivation for teachers. Apart from motivating, they must also be able to provide good role models or examples to their subordinates, in order to develop their subordinates' performance. Principal leadership affects teacher performance because based on observations and interviews it can be seen that the leadership carried out by the principal has been going well, but in the implementation of providing motivation and morale to his subordinates it has not been going well.

Judging from the survey that has been conducted, there is a problem that can be seen from nearly $30 \%$ of teachers lazy in carrying out important tasks (teaching), such as arriving late to school and entering class plus not arranging teacher administration. This behavior, if it occurs continuously, can cause other teachers to follow, so that in this problem the principal has the duty to direct and provide morale for teachers who have poor performance. However, there are still several problems that occur related to teacher work motivation.

In line with research by Asridah (2018), the results of the study show that (1) There is an Influence of Leadership on Performance. This can be seen from the results of the table of the coefficient of the counting value for the Leadership variable (X1) is 22,619, while the t-table value for $n=100$ is 1.66055 . (2) There is an influence of motivation on performance. This can be seen from the results of the tcount coefficient table for the Motivation variable (X2) of 1.034 while the table for $n=100$ is 1.66055 . (3) There is no influence between discipline on performance. This can be seen from the results of the large coefficient table 1.66055. (4) There is an influence of leadership, motivation and discipline on performance. So the value of Fcount $>$ Ftable 1 is 592.198> 2.70 so that H3 is accepted and it can be concluded that Leadership (X1), Motivation (X2), and Discipline (X3) simultaneously have an effect on performance.

\section{Method}

In this study, quantitative research methods were used and the research design was in the form of an influence study, namely to determine the effect of the three variables, namely the independent or independent variable Teacher Motivation (X1), Principal Leadership (X2) and the dependent or dependent variable Teacher Performance (Y). Data collection techniques using documentation and questionnaires.

\section{Results and Discussions}

\section{Hypothesis of Work Motivation on Teacher Performance}

Hypothesis testing criteria, namely if the probability value (Sig.)> A (0.05) then Ho is accepted, or if the probability value (Sig.) $<A(0.05)$ then Ho is rejected. If the calculation of the $t$ distribution is calculated using the formula, the following equation is obtained by [7].

Table $1<$ Hypothesis Testing Criteria >

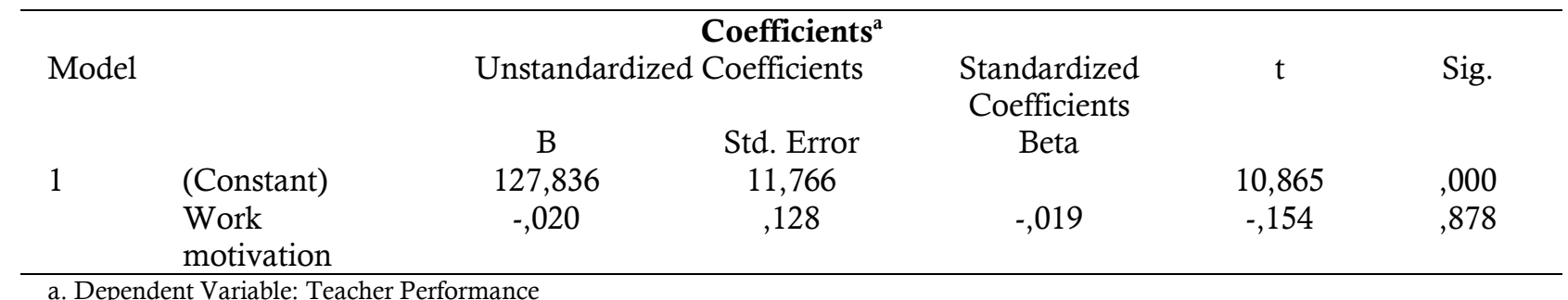


This means that the sig value in the table is $0.878>0.05$, so the Ho variable is accepted and states that there is an effect of work motivation on teacher performance. As for the linear regensia test, the equation is used which can be seen as follows: $\mathrm{Y}=127.836+0.020 \mathrm{X} 1$.

In connection with the results of the simple linear regression equation, it can be interpreted as follows: a) If the work motivation is zero, the teacher's performance at the SD Negeri Lengkiti District is 127.836, b) work motivation has a positive influence on the performance of teachers at SD Negeri Lengkiti District constant of 0.020 if the other variables are considered constant.

To see the influence of the principal's leadership on teacher work performance, in connection with the results of the calculation of the correlation coefficient, the $\mathrm{R}$ value is 0.019 . This means that the influence of work motivation on the performance of SDN teachers in Lengkiti District is $1.9 \%$, the remaining $98.1 \%$ is influenced by other factors which is not a variable in this study. And for the strength of the coefficient on this test is very weak.

\section{Hypothesis of Principal Leadership on Teacher Performance}

Hypothesis testing criteria, namely if the probability value (Sig.) > A (0.05) then Ho is accepted, or if the probability value (Sig.) $<$ A $(0.05)$ then Ho is rejected. If the calculation of the $t$ distribution is calculated using the formula, the following equation is obtained: [7].

Table $2<$ The Calculation of the T Distribution>

\begin{tabular}{|c|c|c|c|c|c|c|}
\hline \multirow{2}{*}{\multicolumn{2}{|c|}{ Model }} & $\begin{array}{r}\text { C } \\
\text { Unst } \\
\text { Co }\end{array}$ & $\begin{array}{l}\text { cients } \\
\text { dized } \\
\text { ents }\end{array}$ & $\begin{array}{l}\text { Standardized } \\
\text { Coefficients }\end{array}$ & \multirow[t]{2}{*}{$\mathrm{t}$} & Sig. \\
\hline & & B & Std. Error & Beta & & \\
\hline 1 & (Constant) & 153,774 & 23,375 & & 6,579 & ,000 \\
\hline & Principal Leadership &,- 230 &, 194 &,- 148 & $-1,188$ & 239 \\
\hline
\end{tabular}

a. Dependent Variable: Teacher Performance

This means that the sig value in the table is $0.239>0.05$, so the Ho variable is accepted and states that there is an influence of the principal's leadership on teacher performance. As for the linear regensia test, an equation is used which can be seen as follows. $\mathrm{Y}=153.774+0.230 \mathrm{X} 2$.

In connection with the results of the simple linear regression equation, it can be interpreted as follows: a) If the work motivation is zero, the teacher's performance at the SD Negeri Lengkiti District is 153,774 , b) work motivation has a positive influence on the performance of teachers at SD Negeri Lengkiti District constant of 0.230 if other variables are considered constant.

To see the influence of the principal's leadership on teacher work performance, in connection with the results of the calculation of the correlation coefficient, the $\mathrm{R}$ value is 0.148 . This means that the magnitude of the influence of the principal's leadership on the performance of teachers in SD Negeri Lengkiti District is $14.8 \%$ the remaining $85.2 \%$ is influenced by factors others who are not variables in this study. And for the strength of the coefficient on this test is very weak.

\section{Hypothesis of Work Motivation and Principal Leadership on Teacher Performance}

Simultaneous testing uses the $F$ test which aims to determine the effect of the independent variables (the effect of work motivation and principal leadership) together on the dependent variable (teacher performance). Hypothesis testing criteria, namely if FSig $>\alpha(0.05)$ then Ho is accepted, or if FSig $<\alpha(0.05)$ then Ho is rejected.

Table $3<$ The Effect of Work Motivation and Principal Leadership>

\begin{tabular}{|c|c|c|c|c|c|c|}
\hline \multicolumn{7}{|c|}{ Coefficients $^{\mathrm{a}}$} \\
\hline \multirow{2}{*}{\multicolumn{2}{|c|}{ Model }} & $\begin{array}{l}\text { Unstan } \\
\text { Coef }\end{array}$ & $\begin{array}{l}\text { dized } \\
\text { ents }\end{array}$ & $\begin{array}{l}\text { Standardized } \\
\text { Coefficients }\end{array}$ & $\mathrm{t}$ & Sig. \\
\hline & & B & Std. Error & Beta & & \\
\hline \multirow[t]{3}{*}{1} & (Constant) & 154,533 & 25,648 & & 6,025 & , 000 \\
\hline & Work motivation &,- 010 & , 128 &,- 009 &,- 075 & ,941 \\
\hline & Principal Leadership &,- 229 & ,196 &,- 147 & $-1,171$ & ,246 \\
\hline
\end{tabular}

a. Dependent Variable: Teacher Performance

Based on the calculations, the multiple linear regression equation is obtained as follows: $\mathrm{Y}=154.533+$ $0.010 \mathrm{X} 1+0.229 \mathrm{X} 2$. In connection with the results of the simple linear regression equation, it can be interpreted as follows: 1) If the motivation for work and leadership of the principal is zero, then the 
performance of the SD Negeri Lengkiti District teacher will be constant (a) of 154.533, 2) Work motivation has a positive influence on the work performance of teachers in SMA Se Muara Telang District, Banyuasin Regency of 0.010 if other variables are considered constant, c. The leadership of the principal has a positive influence on the work performance of teachers in SMA Se Muara Telang District, Banyuasin Regency of 0.229 if other variables are considered constant.

This means that work motivation and principal leadership are important factors in improving teacher performance in schools. To see the effect of the independent variable on the dependent variable using the $\mathrm{F}$ test, the probability value (0.502) is greater than the $\alpha$ value (0.05), while the Fcount value of 4.6974 is greater than Ftable of 3.13 so that $\mathrm{Ha}$ is accepted. This means that there is an effect of work motivation and principal leadership together on the performance of teachers at SD Negeri Lengkiti District.

\section{Discussion}

1. The Effect of Work Motivation on the Performance of Teachers in SD Negeri Lengkiti District A teacher can work professionally if he has high motivation. Teachers who have high motivation will usually carry out their duties energetically and energetically, because there are certain motives or goals behind these actions. Motive is the driving factor that gives him strength, so that he is willing and willing to work hard. It can be concluded that if a teacher has high achievement motivation, he will also achieve high work performance.

The results of hypothesis testing obtained a probability value of $0.878>0.05$, so the Ho variable was accepted and stated that the motivation variable had an influence on teacher performance. This means that there is an effect of work motivation on teacher performance in SD Negeri Lengkiti District. The influence of work motivation on teacher performance is $1.9 \%$, the remaining $98.1 \%$ is influenced by other factors which are not variables in this study.

Based on the description above, it can be concluded that the better the teacher's work motivation, the better the teacher's performance and conversely, the lower the teacher's work motivation, the lower the teacher's performance in SD Negeri Lengkiti District.

From the results of data analysis, it is found that there is an effect of work motivation on teacher performance, this is also in line with research conducted by Sari, AR (2013) which states that work motivation affects teacher performance achievement. The results of the study are also in line with the research conducted by Wati, RDN (2011) which states that in her research there is an effect of work motivation on teacher professionalism. In line with this research, there is also research from [5] which states that in their research it has been found that there is an effect of work motivation on teacher performance.

2. The Influence of Principal Leadership on Teacher Performance at SD Negeri SD Negeri Lengkiti District A leader is a person who inspires, persuades, influences and motivates others. Leadership as the ability to influence or encourage a person or group of people to work voluntarily to achieve certain goals or objectives in certain situations, so that the leadership of the principal is required not only to be able to lead or manage schools, but also to be able to create a conducive atmosphere in the work environment (climate). -maker) so as to improve teacher work performance. Through this research it can be seen that teacher work motivation and principal leadership contribute to teacher performance in SD Negeri Lengkiti District.

Thus, teacher work motivation and principal leadership are needed in improving teacher performance. The results showed that there was a positive and significant influence between principal leadership and teacher performance in SD Negeri Lengkiti District, this was evidenced by the value of the hypothesis testing results obtained by a probability value of $0.239>0.05$, the variable Ho was accepted and stated that the motivation variable had an influence teacher performance. That is, there is an influence of the principal's leadership on teacher performance in SD Negeri Lengkiti District. The magnitude of the influence of the principal's leadership on teacher performance is $14.8 \%$, the remaining $85.2 \%$ is influenced by other factors which are not variables in this study

Based on the description above, it can be concluded that the better the leadership of the principal, the better the performance of the teachers in SD Negeri Lengkiti District, and conversely the lower the leadership of the principal, the lower the performance of teachers in SD Negeri Lengkiti District. From the results of this study also have results that are in line with the research conducted by Wati, RDN (2011) which states that in his research that there is an influence of the principal's leadership on teacher professionalism. 
There is also research that has the same results, namely showing that there is an influence of principal leadership on teacher performance, namely research from [8] besides that it is also based on research by Nasrum which states that in his research it states that there is an influence of the principal's leadership coefficient on teacher performance.

3. The Effect of Work Motivation and Principal Leadership Together on the Performance of Teachers in SD Negeri Lengkiti District.

The results showed that there was a positive and significant relationship between teacher work motivation and principal leadership with teacher performance in SD Negeri Lengkiti district, this was evidenced by the value of the hypothesis testing results obtained by the value of robability $(0.502)$ greater than the value of $\alpha(0.05)$., while the value of Fcount of 4.6974 is greater than Ftable of 3.13 so that $\mathrm{Ha}$ is accepted. This means that there is an effect of work motivation and principal leadership together on the performance of teachers in SD Negeri Lengkiti District.

The magnitude of the influence of work motivation and principal leadership together on teacher work performance in SD Negeri Kecamatan Lengkiti is $44.8 \%$, the remaining $55.2 \%$ is influenced by other factors which are not included in the variable variable in this study

Many factors influence teacher work performance including teacher work motivation and principal leadership. Teacher performance is essentially the result of the interaction between these various factors, including teacher work motivation and principal leadership, where the results of this study also show that teacher work motivation and principal leadership contribute an effective $44.8 \%$ to teacher achievement.

Thus teacher work motivation and principal leadership jointly influence teacher work performance. The better the principal leadership and teacher work motivation, the better the teacher work performance in SMA Se Muara Telang District, Banyuasin Regency. From the results of research that are in line with this study also states that research by Zamroni states that there is an influence of principal leadership and work motivation simultaneously on teacher performance.

\section{Conclusions}

Based on the results of the research and discussion, it can be concluded as follows: 1) There is an influence of work motivation on the performance of SD Negeri Lengkiti District Teachers, 2) There is an influence of the principal's leadership on the Teacher Performance of SD Negeri Lengkiti District, 3) There is an influence of work motivation and principal leadership together on the Teacher Performance of SD Negeri Lengkiti District.

\section{References}

Wukir. (2013). Manajemen SumberDaya Manusia Dalam organisasi Sekolah.

Yogyakarta: Multi Presin

Sagala, S. (2009). Konsep dan Makna Pembelajaran. Jakarta: Rineka Cipta.

Pudjiastuti Enni dan Untung Sriwidodo. (2011). Pengaruh Kompetensi, Disiplin Kerja, dan Kepuasan Kerja terhadap Kinerja Guru SMP Negeri 1 Purwodadi Grobogan. Jurnal.

Siagian, (2013), Manajemen Sumber Daya Manusia. Jakarta: Bumi Aksara

Septiana, Roslena ,Ngadiman dan Elvia Ivada. 2013. Pengaruh Kepemimpinan Kepala Sekolah dan Motivasi Kerja Terhadap Kinerja Guru SMP Negeri Wonosari. Jurnal Pendidikan (Jupe) UNS, Vol 2 No 1 Hal $107 \mathrm{~s} / \mathrm{d} 118$ Agustus 2013

Sunarjono, T. (2012). Kontribusi Kepemimpinan Transformasional Kepala Sekolah dan Iklim Sekolah Terhadap Peningkatan Efektivitas Sekolah Pada SMP Negeri Se- Kabupaten Purwakarta. Tesis S2 Universitas Pendidikan Indonesia.

Kesumawati, Nila dan Ichwan Aridanu. (2017). Statistik Parametrik Penelitian Pendidikan. Palembang: Noer Fikri

Baihaqi, M. I. (2015). Indikator Keberhasilan Kepemimpinan Kepala Sekolah dan Motivasi Kerja Terhadap Kinerja GUru; Jurnal Konstruktivisme, Vol.7

Hermawati, W., Fawaiz, R., \& Nurjanah, L. (2021). Pengaruh Kepemimpinan Transformasional Kepala Sekolah Terhadap Kinerja Guru Di Smp Negeri 2 Susukan Lebak. Jurnal Ekonomi Manajemen, 16(1), 16.

Wicaksono, D. B. (2021). Pengaruh Kepemimpinan Kepala Sekolah Dan Motivasi Kerja Terhadap Kinerja Guru Sekolah Dasar Negeri Di Wilayah Jakarta Timur Ii (Jt 2). Improvement Jurnal Ilmiah Untuk Peningkatan Mutu Manajemen Pendidikan, 8(1), 92-106. 
